\title{
ENRAIZAMENTO IN VITRO DE RAMOS DE MAMOEIRO 'TAINUNG 01' CULTIVADOS SOB LUZ E ESCURO/LUZ
}

\author{
SCHMILDT, Omar ${ }^{1}$ \\ SCHMILDT, Edilson Romais ${ }^{1}$ \\ AMARAL, José Augusto Teixeira do ${ }^{2}$
}

RESUMO: Esse trabalho teve como objetivo avaliar duas condições de cultivo na resposta rizogênica in vitro de ramos micropropagados de mamoeiro (Carica papaya L. 'Tainung 01'). Os ramos submetidos ao anraizamento foram obtidos no quarto subcultivo em meio de multiplicação e cultivados em meio de Murashige e Skoog (1962), suplementado com sacarose a $30 \mathrm{~g} \mathrm{~L}^{-1}$, e AIB a $0,2 \mathrm{mg} \mathrm{L}^{-1}$ solidificado com $7 \mathrm{~g} \mathrm{~L}^{-1}$ de Agar. Foram usados 40 ramos sendo que 20 destes estiveram por sete dias iniciais no escuro e mais 23 dias seguintes na luz sob lâmpadas fluorescentes fornecendo $22,8 \mu \mathrm{mol} \mathrm{m} \mathrm{m}^{-2} \mathrm{~s}^{-1}$ de fluxos de fótons fotossintéticos e 16 horas de fotoperíodo com temperatura controlada em $27 \pm 2^{\circ} \mathrm{C}$. Os outros 20 ramos estiveram todos os 30 dias sob luz nas condições especificadas. Ao final deste período foram avaliados a porcentagem de ramos enraizados, o crescimento dos ramos, o comprimento da maior folha e a massa de calo na base dos ramos. As médias foram analisadas pelo teste $\mathrm{t}$ a $5 \%$ de probabilidade. Pelos resultados obtidos apenas para a variável massa de calo houve diferença estatisticamente significativa sendo que há maior formação de calo na base de ramos cultivados no escuro por sete dias iniciais. Conclui-se que o enraizamento usando $0,2 \mathrm{mg} \mathrm{L}^{-1}$ de AIB possa ser feito tanto sob luz quando escuro/luz. No entanto, por questões de economia de energia, recomenda-se o cultivo na condição escuro/luz.

Palavras-chave: Carica papaya. Auxina. Cultura de tecidos.

SUMMARY: This work aimed to evaluate two culture conditions in vitro in rhizogenic response of micropropagated branches of papaya tree (Carica papaya L. 'Tainung 01'). The branches submitted to rooting were obtained in the fourth subculture in the midst of multiplication and cultivated in culture medium of Murashige and Skoog (1962), supplemented with sucrose at $30 \mathrm{~g} \mathrm{~L}^{-1}$, and IBA at $0.2 \mathrm{mg} \mathrm{L}^{-1}$ solidified with agar at $7 \mathrm{~g} \mathrm{~L}^{-1}$. Were used 40 branches but 20 of these branches were for 7 days starting in the dark and a further 23 days under fluorescent light in providing $22.8 \mu \mathrm{mol} \mathrm{m} \mathrm{m}^{-2}$ flows of photosynthetic photons and 16 hours of photoperiod and temperature controlled $27 \pm 2^{\circ} \mathrm{C}$. The other 20 branches remained under light for 30 days under specified conditions. At the end of this period were evaluated the percentage of rooted branches, the growth of the branches, the length of the largest leaf and the mass of callus at the base of the branches. The means were analyzed by t-test at $5 \%$ probability. By the results obtained only for the variable mass of callus was statistically significant difference being that there was more callus formation at the base of branches grown in the dark for seven days early. It is concluded that the roots using IBA at $0.2 \mathrm{mg} \mathrm{L}^{-1}$ can be done under light or dark / light. However, for reasons of energy saving, it is recommended that the culture condition in the dark / light.

Keywords: Carica papaya. Auxin. Tissue culture.

\section{INTRODUÇÃO}

A fase de rizogênese no processo micropropagativo foi conceituada como estádio III por Murashige, sucedendo aos estádios I e II, que se referem à introdução e multiplicação, respectivamente, de explantes in vitro (MURASHIGE, 1974).

Para o mamoeiro, no entanto, a rizogênese é um dos entraves ao processo micropropagativo (TEO; CHAN, 1994; YU et al., 2000; ROHMAN et al., 2007; TALAVERA et al., 2009; FERREIRA et al., 2011). Segundo Teo e Chan (1994), é mais fácil induzir enraizamento em culturas como cálamo, citros e

\footnotetext{
${ }^{1}$ Professor Doutor no Centro Universitário Norte do Espírito Santo (CEUNES) da Universidade Federal do Espírito Santo (UFES), Rodovia BR 101 Norte, km 60, Bairro Litorâneo, 29932-540, São Mateus/ES. E-mail: omar-

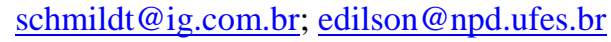

2 Professor Doutor no Centro de Ciências Agrárias (CCA) da Universidade Federal do Espírito Santo (UFES), Alto Universitário, Caixa Postal 16, Centro, 29500-000, Alegre/ES. E-mail: jata@cca.ufes.br
} 
gengibre do que em mamão.

O processo de enraizamento é muito complexo, incluindo fatores fisiológicos, bioquímicos e biológicos (fatores internos) que interagem com os fatores externos (RADMANN et al., 2002). A complexidade aumenta em função do genótipo e do meio de cultura (GEORGE et al., 2008). Além disso, é importante que junto com a formação de raízes, haja crescimento dos ramos. Taiz e Zeiger (2009) descrevem que em dicotiledôneas, este crescimento é estimulado quando ramos são tratados com auxinas entre $10^{-5}$ e $10^{-6}$ molares. Estes resultados foram comprovados em mamoeiro com os trabalhos de Kabir et al. (2007) com o cultivar 'Shahi', e de Ferreira et al. (2011) com 'Tainung 01', usando AIB a 2,0 mg L'-1 e a $0,2 \mathrm{mg} \mathrm{L}^{-1}$, respectivamente.

Quanto às auxinas usadas no enraizamento in vitro, Nissen e Sutter (1990) relatam que o AIA é foto-oxidado rapidamente no meio de cultura (50\% em 24 horas), o AIB é levemente foto-oxidado (10\% em 24 horas) e ao ANA é o mais estável. Na rizogênese em mamoeiro comparando AIB e ANA, vários autores verificaram que a porcentagem de enraizamento é maior com o uso de AIB (RAJEEVAN; PANDEY, 1986; DREW, 1987; KABIR et al., 2007). Quando à qualidade do sistema radicular, Rajeevan e Pandey (1986) verificaram que as raízes formadas na presença de AIB são normais e os ramos apresentam bom crescimento, enquanto que o uso de ANA forma raízes grossas e anormais, além de causar senescência dos ramos. O AIB é o regulador de crescimento mais usado na rizogênese in vitro (GEORGE et al., 2008).

Dentre os fatores físicos que podem afetar a rizogênese, a luz é um dos principais. Segundo George et al. (2008), a formação de raízes à luz é muitas vezes necessária, desde que, inicialmente o material vegetal passe um período no escuro. Neste contexto, Drew (1987) verificou que, quando a região basal dos ramos de mamoeiro foi exposta à luz, a iniciação de raízes foi inibida; outrossim, após as raízes terem iniciado, seu crescimento aumentou, em função da incidência de luz sobre as folhas. Drew (1988) verificou que a exclusão da luz, pela pintura dos tubos na sua base, permitiu que houvesse uma melhora no início do enraizamento. Nesta mesma linha, Drew et al. (1993) verificaram que houve melhora no enraizamento e no crescimento dos ramos de mamoeiro in vitro quando os ramos passaram pela fase de escuro por 2 dias e posterior cultivo sob luz.

Nesta mesma linha de trabalho desenvolvida pelo Dr. Drew, Yu et al. (2000) enraizaram eficientemente ramos de mamoeiro 'Tainung 02' com a prévia exposição dos ramos ao escuro por sete dias. Estes autores sugerem que a principal vantagem foi a redução dos custos na micropropagação. Há carência de informações na literatura sobre a resposta do mamoeiro 'Tainung 01 ' à rizogênese in vitro com a prévia exposição dos ramos ao escuro.

Este trabalho teve por objetivo avaliar a rizogênese in vitro de ramos de mamoeiro 'Tainung 01' submetidos tanto à luz por todo período de cultivo quanto submetidos à condição escuro/luz.

\section{MATERIAL E MÉTODOS}

O presente trabalho foi conduzido no Laboratório de Biotecnologia vegetal do Centro de Ciências Agrárias da Universidade Federal do Espírito Santo (CCA/UFES), localizado no município de Alegre-ES.

Ramos micropropagados de mamoeiro (Carica papaya $\mathrm{L}$.) 'Tainung 01 ' geração $\mathrm{F}_{1}$, foram usados para o enraizamento in vitro. Estes ramos foram obtidos a partir do quarto subcultivo em meio de cultura proposto por Schmildt et al. (2007). Os ramos foram padronizados com tamanho de $1,5 \mathrm{~cm}$ e com quatro folhas visíveis, como proposto por Schmildt et al. (2010).

O meio de enraizamento foi constituído de sais e vitaminas do meio de Murashige e Skoog (1962) suplementado com $30 \mathrm{~g} \mathrm{~L}^{-1}$ de sacarose e $0,2 \mathrm{mg} \mathrm{L}^{-1}$ de ácido 3-indolbutírico (AIB), com pH ajustado em 
5,7 antes da adição de agar $\operatorname{Vetec}^{\circledR}$ a $7 \mathrm{~g} \mathrm{~L}^{-1}$. Os ramos foram inoculados individualmente em tubos de ensaio de $25 \times 150 \mathrm{~mm}$ contendo $20 \mathrm{~mL}$ de meio de cultura e mantidos em sala de cultura em duas condições, as quais constituíram os dois tratamentos, cada um com 20 tubos de ensaio, quais sejam: a) sete dias iniciais no escuro e mais 23 dias seguintes na luz sob lâmpadas fluorescentes fornecendo 22,8 umol $\mathrm{m}^{-2} \mathrm{~s}^{-1}$ de fluxos de fótons fotossintéticos, 16 horas de fotoperíodo, e com temperatura controlada em $27 \pm 2^{\circ} \mathrm{C}$; b) todos os 30 dias de tratamento sob luz com lâmpadas fluorescentes fornecendo $22,8 \mu \mathrm{mol} \mathrm{m}{ }^{-2}$ $\mathrm{s}^{-1}$ de fluxos de fótons fotossintéticos, 16 horas de fotoperíodo, e com temperatura controlada em $27 \pm 2^{\circ} \mathrm{C}$.

Aos 30 dias de cultivo, foram feitas as avaliações para rizogênese em mamoeiro, conforme sugeridas por Schmildt et al. (2010): porcentagem de ramos enraizados; crescimento dos ramos; comprimento da maior folha; massa de calo na base dos ramos. A porcentagem de ramos enraizados foi analisada pela estatística descritiva com a construção de um intervalo de confiança a 5\% conforme Snedecor (1965). As demais variáveis tiveram suas médias analisadas estatisticamente pelo teste t a 5\% de probabilidade, com auxílio do programa Bioestat 5.0 (AYRES et al., 2007).

\section{RESULTADOS E DISCUSSÃO}

As condições de cultivo não influenciaram a porcentagem de enraizamento dos ramos $(p>0,05)$ como pode ser visto na figura 1. Estes resultados são diferentes dos verificados por Drew (1987) que afirmam que a incidência de luz sobre a região basal dos ramos de mamoeiro na fase de indução de raízes, inibe a rizogênese. No entanto, o autor não menciona qual a cultivar usada, sendo que a rizogênese é influenciada pelo genótipo (GEORGE et al., 2008) como verificado em mamoeiro em clones de 'Eksotika' (CHAN e TEO, 2002) e de 'Tainung 01' geração $\mathrm{F}_{2}$ (FERREIRA et al., 2011) e entre diferentes cultivares dióicas (SAHA et al., 2004).

O percentual de enraizamento ficou em torno de $65 \%$, semelhante ao verificado por outros autores que trabalharam com mamoeiro (YU et al. 2000; KABIR et al., 2007; TALAVERA et al., 2009). Yu et al. (2000) usaram AIB a 0,5 $\mathrm{mg} \mathrm{L}^{-1}$ em mamoeiro 'Tainung 02' cultivado por sete dias no escuro seguido de 21 dias sob luz e, KABIR et al. (2007), usaram AIB a 0,2 $\mathrm{mg} \mathrm{L}^{-1}$ em mamoeiro 'Shahi' em cultivo sob luz.

Figura 1 - Porcentagem de enraizamento in vitro de ramos de mamoeiro 'Tainung 01'30 dias após submetidos a duas condições de cultivo. Alegre-ES, 2006 (barras verticais indicam intervalo de confiança a 5\% para a média, conforme Snedecor, 1965).

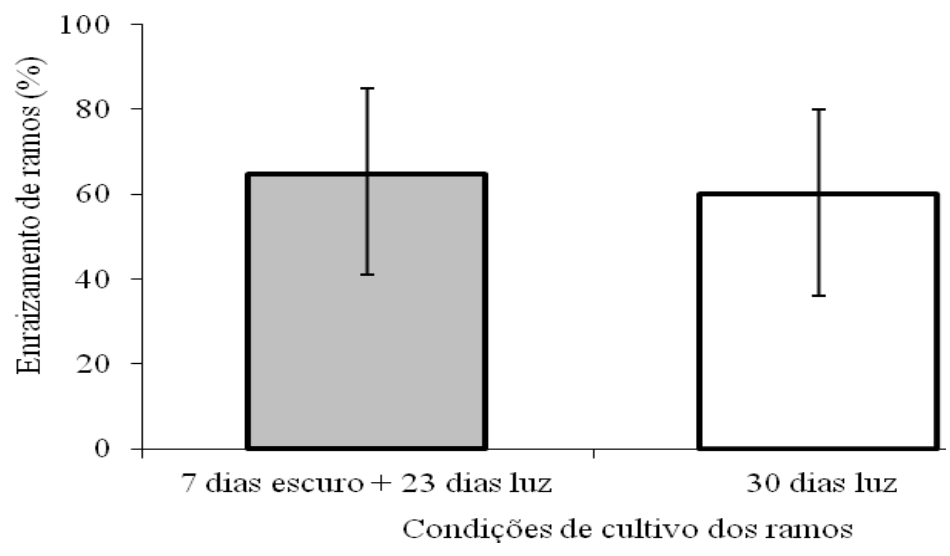

O enraizamento em presença de luz pode ser melhorado se o material cultivado passar por um período de escuro na presença de auxina; isto, segundo George et al. (2008), estaria relacionado com a participação de AIA endógeno na fase de indução e teria seus teores diminuídos se os ramos fossem dispostos à luz, nessa fase. Estas proposições não puderam ser comprovadas com os sete dias de 
precondicionamento dos ramos a $0,2 \mathrm{mg} \mathrm{L}^{-1}$ de AIB adotados nesse trabalho.

As variáveis crescimento de ramos e diâmetro da maior folha, também não foram influenciadas ( $\mathrm{p}$ $>0,05$ ) pelas condições de cultivo (Figura 2). Os ramos cresceram em média 1,3 cm. Taiz e Zeiger (2009) explicam que há tendência do crescimento de ramos durante a rizogênese in vitro na presença de AIB entre 0,2 e 2,0 $\mathrm{mg} \mathrm{L}^{-1}$ e esse crescimento se deve principalmente ao alongamento celular, em virtude da capacidade das auxinas promoverem a extensão da parede celular. Neste trabalho, utilizou-se AIB a 0,2 $\mathrm{mg} \mathrm{L}^{-1}$, que também é concentração ótima para indução de raízes adventícias (TAIZ; ZEIGER, 2009). Ressalta-se que, segundo Nissen e Sutter (1990), o AIB é degradado em média 10\% nas primeiras 24 horas de exposição à luz e que, no entanto, neste trabalho a possível degradação de AIB não afetou o crescimento dos ramos e nem a indução de raízes.

Figura 2 - Crescimento de ramos e comprimento da maior folha em ramos de mamoeiro 'Tainung 01' 30 dias depois de submetidos a duas condições de cultivo in vitro. Alegre-ES, 2006. (barras verticais indicam erro padrão da média e letras, para cada característica, iguais indicam igualdade estatística pelo teste t com $\alpha$ a $5 \%)$.

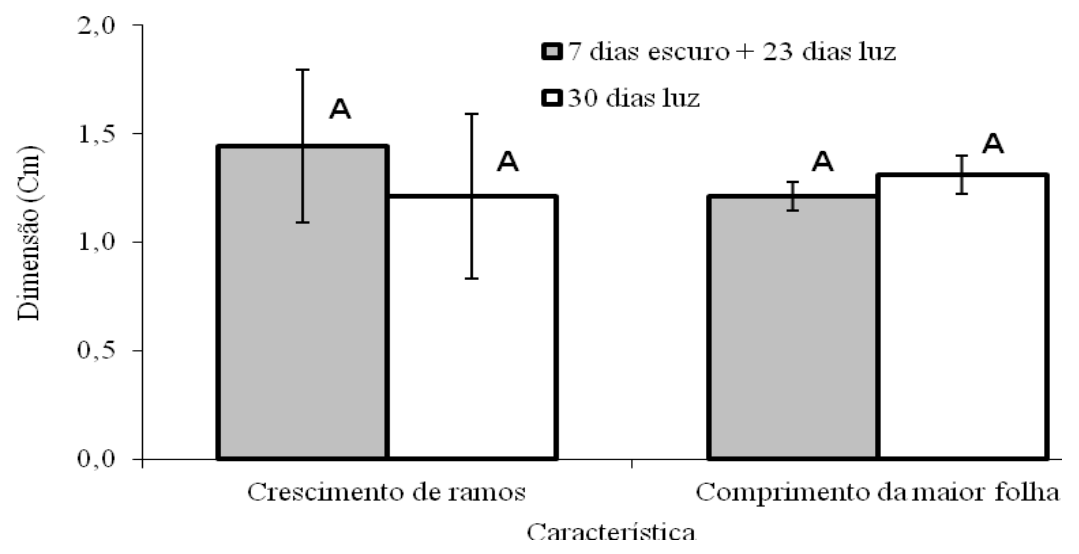

A massa de calo na base dos ramos foi influenciada $(\mathrm{p}<0,05)$ pelas condições de cultivo (Figura 3). A formação de massa de calo pode ser interessante para trabalhos de organogênese ou embriogênese somática. No entanto, não é interessante para o enraizamento, quando formado em grande quantidade, pela possibilidade de formação de raízes a partir desse calo, com geotropismo negativo e sem conexão com o sistema vascular dos ramos (SCHMILDT et al., 2010). Neste trabalho, o calo não foi prejudicial, pois todas as raízes estavam aderidas aos ramos e com geotropismo positivo.

Figura 3 - Massa de calo na base de ramos de mamoeiro 'Tainung 01' submetidos a duas condições de cultivo. Alegre-ES, 2006 (barras verticais indicam erro padrão da média e letras diferentes indicam diferença estatística pelo teste t com $\alpha$ a $5 \%$ ).

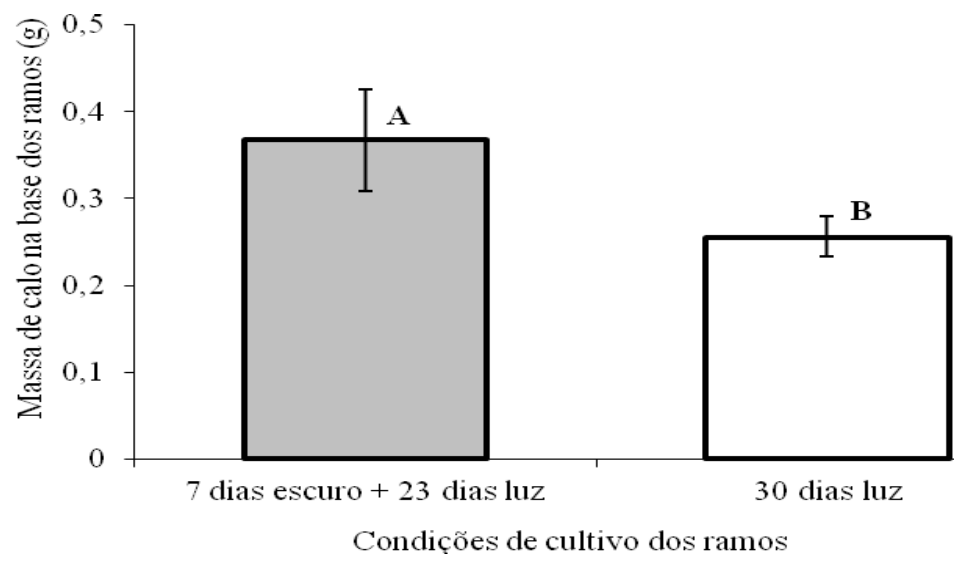




\section{CONCLUSÃO}

Nas condições em que foi realizado este trabalho, a rizogênese em ramos de mamoeiro 'Tainung 01 ' não é influenciada pela exposição ou não ao escuro na fase inicial e, portanto, em termos econômicos, recomenda-se cultivar os ramos por sete dias no escuro seguidos de mais 23 dias sob luz.

\section{REFERÊNCIAS}

AYRES, M.; AYRES, M. JR.; AYRES, D. L.; SANTOS, A. S. Bioestat: Aplicações Estatísticas nas Áreas das Ciências Biomédicas. 5.ed. Belém: Mamirauá, 2007.

CHAN, L. K.; TEO, C. K. H. Micropropagation of Eksotika, a malaysian papaya cultivar, and the field performance of the tissue culture derived clones. Acta Horticulturae, n. 575, p. 99-105, 2002.

DREW, R.A. The effects of medium composition and conditions on in vitro initiation and growth of papaya (Carica papaya L.). Journal of Horticultural Science, v. 62, n. 4, p. 551-556, 1987.

DREW, R.A. Rapid clonal propagation of papaya in vitro from mature field-grown trees. HortScience, v.23, n. 3, p.609-611, 1988.

DREW, R.A.; McCOMB, J.A.; CONSIDINE, J.A. Rhizogenesis and root growth of Carica papaya L. in vitro in relation to auxin sensitive phases and use of riboflavin. Plant Cell, Tissue and Organ Culture, v. 33, n. 1, p. 1-7, 1993.

FERREIRA, J.P.et al. Enraizamento in vitro de clones de mamoeiro 'Tainung 01'. Revista Ciência Agronômica, v. 42, n. 2, p. 563-566, 2011.

GEORGE, E. F.; HALL, M. A.; DE KLERK, G. J. Plant propagation by tissue culture: volume 1. the background. 3 ed. Dordrecht: Springer, 2008.

KABIR, A.H.et al. Effect of growth regulators and carbon sources on axillary shoot proliferation from shoot-tip explants and successful transplantation of papaya (Carica papaya L.). Biotechnology, v. 6, n.2, p. 268-272, 2007.

MURAShige, T. Plant propagation though tissue culture. Annual Review of Plant Physiology, v.25, p.135-166, 1974.

MURASHIGE, T. ; SKOOG, F. A revised medium for rapid growth and bioassays with tobaco tissue cultures. Physiologia Plantarum, v.15, p.473-497, 1962.

NISSEN, J.S.; SUTTER, E.G. Stability of IAA and IBA in nutrient médium of several tissue culture procedures. HortScience, v. 25, p. 800-802, 1990.

RADMANN, E. B.; FACHINELLO, J. C.; PETERS, J. A. Efeito de auxinas e condições de cultivo no enraizamento in vitro de porta-enxertos de macieira 'M-9'. Revista Brasileira de Fruticultura, v. 24, n. 03, p. 624-628, 2002.

RAJEEVAN, M. S.; PANDEY, R. M. Lateral bud culture of papaya (Carica papaya L.) for clonal propagation. Plant Cell, Tissue and Organ Culture, v. 6, n. 2, p.181-188, 1986.

ROHMAN, M. M. et al. Lateral bud culture of papaya (Carica papaya) for clonal propagation. Biotechnology, v. 06, n. 03, p. 339-343, 2007.

SAHA, M.; PHATAK, A.; CHANDRA, N. In vitro culture studies in four dioecious varieties of Carica papaya L. using axillary buds from field-grown plants. Journal of Tissue Research, v. 4, n. 2, p. 211214, 2004. 
SCHMILDT, O.; SCHMILDT, E.R.; AMARAL, J.A.T. do. Cinetina e ANA na multiplicação in vitro de mamoeiro 'Tainung 01'. Scientia Agraria, v. 08, n. 01, p. 55-60. 2007.

SCHMILDT, E. R. et al. Níveis de ácido indol butírico (AIB) no enraizamento in vitro de microestacas de mamoeiro 'Tainung 01'. Acta Scientiarum - Agronomy, v. 32, n. 01, p. 125-129, 2010.

SNEDECOR, G.W. Statistical methods. 15. ed. Iowa, USA: Ames, 1965.

TAIZ, L., ZEIGER, E. Fisiologia vegetal. 4. ed. Porto Alegre: Artmed. 2009. 848p.

TALAVERA, C.et al. Acclimatization, rooting and field establishment of micropropagated papaya plants. Acta Horticulturae, n. 812, p. 373-378, 2009.

TEO, C.K.H.; CHAN, L.K. The effects of agar content, nutrient concentration, genotype and light intensity on the in vitro rooting of papaya microcuttings. Jounal of Horticultural Science, v. 69, n. 2, p. 267-73, 1994.

YU, T. A. et al. Efficient rooting for establishment of papaya plantlets by micropropagation. Plant Cell Tissue and Organ Cult 